\title{
Developing an Integrative Marketing Theory: Re-conceptualizing Valuation, Market Theory and Exchange
}

\section{Leon Miller}

School of Business and Governance, Tallinn University of Technology, Tallinn, Estonia

Email address:

leonmonroemiller@yahoo.com

\section{To cite this article:}

Leon Miller. Developing an Integrative Marketing Theory: Re-conceptualizing Valuation, Market Theory, and Exchange. International Journal of Accounting, Finance and Risk Management. Vol. 3, No. 2, 2018, pp. 5-15. doi: 10.11648/j.ijafrm.20180302.11

Received: September 14, 2018; Accepted: September 28, 2018; Published: October 23, 2018

\begin{abstract}
Marketing specialists play a vanguard role in heralding a new perspective on exchange that prompts a reconceptualization of valuation, marketing theory, and economic value theory. However the literature is inadequate in doing so in terms that are relevant for practitioners how the conceptualizations can be developed into a theoretical model for improving organizational and social-economic performance. This article contributes to marketing literature and to literature explaining how to improve organizational and social-economic performance by proposing a strategy by which the marketing perspective on exchange and valuation can be developed into a framework for an integrative marketing theory. That is to say that the article explains how and why marketing conceptualizations of valuation and exchange provide a source for determining the factors that apply as a multi-level and multi-dimensional approach to improving performance (i.e. increasing the performance of organizations and institutions in ways that create satisfactory and beneficial outcomes for a larger number of social stakeholders). This article is designed as an exploratory study of historical and contemporary conceptualizations of exchange, the market, and valuation as the means of collecting the necessary conceptual data for developing an integrative marketing theory. The exploratory study is the means for determining factors that can be applied as a multi-dimensional strategy for performance improvement. The conceptual data is triangulated to determine the conceptual categories that are expressed as factors that can be employed as a marketing model for satisfying the interests of stakeholders. In addition the article contributes to scholarship on marketing ethics by indicating how marketing theory increases the competitive advantage of businesses in a way that satisfies concerns regarding social responsibility.
\end{abstract}

Keywords: Co-generative, Functionalism, Formal Categorizations, Axiomatic System, Bridging Mechanism

\section{Introduction}

As the marketing profession evolved its specialists envisioned the possibility of the market becoming a networked sphere where agents interact to co-create outcomes that satisfy stakeholders and increase public value. During the rise of the mass production and mass consumption era marketing specialists were characterized as sales personnel for business firms. In other words business owners thought of marketing professionals as experts in increasing the firm's ability to extract value. Marketing specialists felt that this narrow perspective hindered their effectiveness for executing aspects of their profession that involve the elevation of society and making propositions that satisfy both the material and the eco-aesthetic needs of society. Thus, when the sales department of businesses transformed into marketing departments its professionals acknowledged the importance of operating in accordance with the full scope of their profession.

Marketing professionals realized that enhancing organizational performance and promoting market exchange only reflect limited aspects of what the marketing profession encompasses. They felt obliged to demonstrate the multidisciplinary scope of the profession - which includes motivation and persuasion, rigorous scientific research, the creative arts, a connection with social psychology, with communication theory, semiotics, and with aesthetics. In addition, marketing specialists also engage in research regarding the neural sciences, scientific analyses of the ontological basis of human nature, and research regarding the ontological basis of the neurological impulses influencing humanity's value preferences. [1] Subsequently, with the 
shift toward a Humanistic conception of motivation and organizational activity marketing professionals began to realize the potential their profession has as a bridging mechanism that links knowledge from a social psychological perspective on human values with a social economic perspective on how such knowledge can contribute to enriching society. [2] That is to say that marketing specialists envisioned a way in which their expertise in exchange could be integrated with their expertise in creating value to progress society, contribute to cultural arts, enrich the ecoaesthetic dimensions of society, and elevate the overall human experience. [3].

Specialists increasingly claimed that the market is " $\mathrm{A}$ forum for conversation and interactions between consumers, consumer communities, and firms". [4] This resulted in a gradual re-conceptualization of notions of valuation, exchange, and economic value theory. The reconceptualization was partially initiated by the emergence of the knowledge-based economy that places an emphasis on value management. In other words, the technological age initiated a shift from the value in exchange, firm-centric emphasis on tangible products, the goods-dominant perspective on market exchange, and a value extraction approach to firm-customer relations. [5] The new view stresses increasing internal and external relational capital, creating internal and external networks of collaborative interaction, and integrating the knowledge generated by these networks into value creation activities. The new view proposes that engaging stakeholders in co-creating value increases customer satisfaction and loyalty. Thus, contemporary marketing literature stresses that firms increase their competitive advantage by adopting the value in use, client centric, co-creation of value, integrative, servicedominant view of market activity. [5]

Subsequently, the re-conceptualization of exchange activity began to have enormous impact on organizational literature. [4-7] However, although marketing specialists have played a vanguard role in announcing the resurgence of the value in use concept and the necessity for reconceptualizing economic value theory the literature has been inadequate in explaining the concepts in terms that are most relevant to practitioners. That is to say that the literature has been inadequate in explaining how to apply the concepts as a multi-dimensional integrative strategy for improving performance. [8] In this respect, the literature has also been inadequate in explaining how the recent reconceptualizations contribute to marketing theory development.

This article fills the gap in the literature by explaining how to develop the concepts related to the market, exchange, and valuation into the framework for an integrative marketing theory. In doing so, the article also contributes to resolving the dichotomy between social and economic value theory by explaining how a marketing perspective on exchange and valuation can be a means for integrating resources for the benefit of all participants in the exchange network. [9] The author does so by addressing three research questions:
Is there inherent in the literature on the market, exchange, and valuation key principles and concepts that can be developed into an integrative marketing theory?

Can an integrative marketing theory contribute to resolving the long-standing dichotomy between the value in exchange and value in use perspectives on economic value?

Can the principles and concepts related to the market, exchange, and valuation be developed into a framework for co-creating satisfactory outcomes for stakeholders - e.g. in terms of establishing a model for the market operating as a public sphere where agents employ Constructivist/Structuration-type processes to co-create an increase in benefits for a larger number of social stakeholders?

There are three assumptions that shape the direction this article takes in developing the conceptual framework for a marketing strategy for improving social-economic performance. First, an exploratory study of conceptualizations of the market, exchange, and valuation is the basis for determining the foundational principles and concepts that can be applied as the basis for developing an integrative marketing theory. Second, recent conceptualizations of exchange are compatible with the systems theory of organizations, social-economic systems, and sustainability thus systems theory is a viable source from which to derive concepts and principles for an integrative marketing theory. $[10,11]$ Third, a conceptual framework for co-creating beneficial relationships between structures and agents and for democratizing value creation can be derived from the concepts and principles inherent in the literature on the market, exchange, and valuation. [12-16]

This article proceeds with section two explicating foundational conceptualizations of the market that describe it as a public value creation sphere mediated by Constructivist/Structuration-type interactions between a social-economic system (the structure) and its agents (the public) in order to create increased benefits for those within the system. Section three explains the strategy for developing a theoretical and methodological framework for exchange that can be applied by practitioners to improve performance and/or employed by other researchers to test the validity of an integrative marketing theory. This includes an explanation of how the principles and concepts connected with an integrative marketing theory can be expressed in terms of a model for improving organizational and social-economic performance. Section four concludes the article by summarizing why an integrative marketing theory contributes to improving organizational and social-economic performance and creates satisfactory and beneficial outcomes for a larger number of social stakeholders.

\section{The Conceptual Foundation of Valuation}

The American Marketing Association announced a paradigm shift in the fundamental construct of marketing in 
1985 when it replaced the phrase "Marketing is ... to create exchanges" with "Marketing is a function and a set of processes for creating, communicating and delivering value to customers in ways that benefit the organization and its stakeholders". Although the change clearly represented a fundamental shift from the way marketing was defined during the early part of the $20^{\text {th }}$ century it also indicates a return to the foundational principles upon which the market, exchange, and the value concept are based. The new definition of marketing also reflects Western Civilization's foundational perspective on managing wealth, social economics, social responsibility, ethics, economic philosophy, and concepts that serve as the basis for theory development.

The contemporary literature refers to the foundational perspective on the market, exchange, and valuation as a primary source for concepts and principles that explain the relationship between market activity and increasing the value created for stakeholders. [20, 21, 16] This section of the article provides a brief overview of the foundational perspective of the market, exchange, and valuation; explains how it came to have an impact on contemporary perspectives on market interactions and the practice of marketing; and adds to the contemporary literature by explaining how the foundational conceptualizations contribute to developing an integrative marketing theory. This section also includes an explanation of the discrepancy regarding economic value theory and why it has persisted to be a problem that renowned scholars have addressed: e.g. scholars of The Philosophy of Science like Aristotle, Max Weber, and Talcott Parsons. In addition, this section explains the rationale behind claiming that a framework for testing the applicability of an integrative marketing theory can be derived from the foundational concepts and principles. [25, 26].

Developing a framework for an integrative marketing theory requires generating a hypothesis "That can be tested through subsequent empirical verification processes in routine research". However, because a study of the literature regarding the role that market activity plays in creating value prompts a re-conceptualization of economic value theory developing a theoretical framework involves more than determining how exchange and valuation can be described in terms relevant to marketing theory. Developing a theory that represents a fundamental shift in the outlook on marketing involves "Scientific activity occurring at three levels paradigms, perspectives, and puzzle solving". Conceptualizations of exchange and valuation have been part of management and economic theory since the inception of Western perspectives on managing wealth and market activity. From the very beginning there were indications of a discrepancy between the value in exchange and the value in use economic value theories. For example, Aristotle is credited with being the first to stress a dichotomy in the value concepts and he claimed that if unresolved the prospects for mutually beneficial and satisfactory exchange would be reduced.

Aristotle is a pioneer in analyzing valuation and he proposed a theoretical model that would "Increase the capacity of individuals and organizations to think, act, and [relate] in value-rationality terms". Aristotle thought of market exchange as a social process that individuals engage in to maximize mutually beneficial transactions and to create the good life. He coined the concept value in use to describe an approach to exchange that improves the quality of social life and he asserted that market exchange is the key to creating a flourishing society. He believed that engaging in exchange in the endeavor to create the good life is preferable - as opposed to the endless effort to amass wealth and increase the quantity of things in one's life. [31-33] Thus, Aristotle believed that value in use (rather than value in exchange) has a better chance of resulting in mutually satisfactory outcomes and more closely reflects exchanges that create an improved quality of life for social stakeholders.

Aristotle is also credited with introducing a theoretical and methodological framework for analyzing the connection between intentional actions and valuation. He proposed Action Theory as a viable approach to analyzing the ontological basis of value-rationality, as an effective means for researching social interactions, and effective when research involves deliberation about value ends. [34, 35] Aristotle introduced the earliest conceptualizations of Action Theory to address ethical questions about the connection between individual freedom and individual responsibility plus conceptualizations for how to establish beneficial interactions with others and with the environment. [36, 37] Aristotle claimed that Action Theory is especially useful when endeavoring to analyze exchange, when analysis involves determining the motivation behind actions, and when research involves deliberation about value ends.

In terms of contributing to a pragmatic approach to researching the relationship between market activity, value creation, and improving social economic performance Action Theory evolved into Social Action Theory to become a relevant theoretical tool for researching exchange because it is inclusive of the normative aspects of human social relations and it "Centers on a co-generatively structured encounter between the worlds of practical reasoning and those of scientifically constructed knowledge, integrating practitioners and professionals in the same knowledge generating process that it calls co-generative learning". That is to say that Aristotle conceived of Action Theory as a means for gaining reliable knowledge of how interactions with others and with the environment - can increase benefits for larger segments of society. Aristotle regarded the interactive approach to gaining reliable knowledge (as was initially proposed by Socrates) as "The model form of human social action". [40, 41]

Aristotle proposed the integrative methodology as essential for analyzing a phenomenon with such multi-dimensional complexity as the relationship between markets, managing natural resources, and human values. [42 \& 43] Aristotle's approach to researching valuation was integrative in that he believed that individual well-being, social flourishing, good management, and improving social economic performance 
are based on understanding the interface between creating beneficial relationships with others and having beneficial relations with the natural order. Thus there were aspects of his perspective that are related to sustainability socialeconomic planning. Aristotle established a methodology for addressing the interconnection between value tangibles and intangibles, their relevance in the human experience, their relevance to market exchange, to productive activity, and to creating value thus to social action. [44, 45]

Aristotle's market theory, his economic philosophy, and his theoretical approach continued to be the established view of political economy (with some slight modifications) until the establishment of classical economics by Adam Smith. Smith also acknowledged the dichotomy between the value theories. However, Smith, at the time of the emergence of the industrial age, Western expansionism, mercantilism, and colonialism placed the emphasis on wealth generation, material assets, the rationality of utility maximization, and rational choice (i.e. rational self-interest) thus exchange value. This change prompted a pendulum swing in the direction of emphasizing that the market is an arena where businesses try to capture value. "Smith's focus on nominal value and tangible exchange represented a departure from the previously accepted focus on use-value and has had critical implications for the development of economics and the understanding of market exchange". [47, 48].

Smith claimed that natural forces create a providential effect on social interactions which work to benefit market activity when agents are allowed to freely interact in pursuit of their interests - which he believed is in accord with their natural rights. Thus, Smith also envisioned the market as a center for interactive public engagement which could create social dynamics that would reduce the problem of politicaleconomic and/or marketing forces influencing an individual's freedom of choice. That is to say that he conceived of a way of resolving the tension between self-interest and moral sentiments. [49, 50] Although Smith's value theory and notion of wealth generation were ingenious contributions to Modernity and to the ability of nations to increase wealth there were problems resulting from the unresolved discrepancy between the value concepts that became increasingly apparent as the industrial era evolved into the knowledge age. Smith's emphasis on value in exchange, tangible assets, utility value, and nominal value were the outgrowth of his appreciation for Newton's materialistic perspective on ontology. Materialism - which was the dominant perspective at the time was also evident in Karl Marx's dialectics and economic theory and, as well, in Frederick Taylor's emphasis on tangible material incentives, plus on the impact that Behaviorism had on organizational activity and marketing (e.g. the emphasis on the corporal aspect of human psychology). [51, 52] At the beginning of the $20^{\text {th }}$ century the marketing paradigm was rooted in economics and Behaviorism which prompted an emphasis on the power to influence consumers by means of stimulus or incentives that motivate the desire to satisfy instrumental material needs and increase consumption. \&.
The value in exchange and mass consumption approach to firm-client relations dominated the way professionals in the early part of the $20^{\text {th }}$ century thought of the practice of marketing, its strategies, the ethics of marketing, and social responsibility. In other words, marketing activity was based on the conviction that achieving success requires the indisputable necessity of selling as a strategy for capturing value. The belief was that the selling process is based on applying the same scientific methods that were successful in the fields of production, economics, engineering, and Behavioral Psychology. During this era the marketing profession was associated with "Advertising, retailing, channels of distribution, product design and branding, pricing strategies, and consumption behavior - all analyzed from the perspective of companies, industries, or even whole economies".

The return to the foundational principles for exchange and a marketing emphasis on creating mutually satisfying and beneficial outcomes was prompted by Wroe Alderson who is regarded as the father of modern marketing. Alderson, like Aristotle, proposed a theoretical framework for marketing based on his conceptualization of the foundational approach to social flourishing - in line with the relational and integrative systems models. [57, 58] Alderson was deeply concerned about theory development, the very nature of marketing theory as a particular branch of The Philosophy of Science, and "Conceptualizations of the underlying reality which the science undertakes to study". He used the term Functionalism to describe his framework to analyzing the place of marketing in the social sciences.

However, recognition of Alderson's unique contribution to contemporary perspectives on marketing was diminished due to a spillover between Alderson's prescriptions for Functionalism (which were partially influenced by Talcott Parson's views on social economics and Social Action Theory) and those of another emerging theoretical trend also based on Functionalism (influenced by Dewey's aesthetics, his ideas about semiotics, symbolic design, cultural arts, social-economic development, environmental aesthetics, social psychology, and his communication philosophy). [6062] Fortunately, Alderson views were distinguished by his initiating "The broadening movement as an effort to free the marketing paradigm from the narrow confines of commercial marketing and to show its application to a far larger number of contexts in which exchange and relationship activities take place".

Interest in an expanded perspective on marketing prompted marketing researchers to reconsider value rationality, rational choice, and economic exchange. In addition, the blurring of the difference between the two perspectives on Functionalism created an overlap in the marketing professional's sense of identity and purpose. This resulted in the field not only evolving into a science of economic exchange but also into a discipline committed to a rigorous analysis of the social-economic impact of synthesizing science and aesthetics/art. Marketing professionals also undertook the challenge of analyzing the 
impact of communication technology and technologically facilitated networks on co-creating social reality. [65, 66].

The increased interests in integrating the various dimensions of marketing also sparked an emphasis on relational marketing and value creation as significant aspects of how to improve organizational and social-economic performance. Consequently, increasing value creation capabilities and external capital became the primary intention or focus of an organization's internal and external operations. The shift also prompted re-conceptualizing the marketing perspective on the value rationality underlying economic exchange. However, it also increased the necessity for a theoretical model for analyzing the interaction between the social-economic system and the market in which the economy is embedded - i.e. the interaction between a socialeconomic system (the structure) and its agents (its stakeholders).

\section{Developing a Framework for an Integrative Marketing Theory}

A primary premise of this article is that although there is much marketing literature heralding the significance of the new perspective on market exchange the literature does not provide a comprehensive explanation of the factors that apply as a marketing strategy for creating benefits deemed satisfactory by various stakeholders. This section of the article contributes to filling that gap by indicating how marketing conceptualizations of exchange can be described as the general categories of an integrative marketing theory. That is to say that developing a theory for applying marketing conceptualizations of value creation to organizational and social-economic performance demands formulating "A systematically related set of statements, including some law-like generalizations that is empirically testable".

Section 3.1 explains a marketing approach to theory development and how it can be applied to conceptualizations of the market as a public value creation sphere. Section 3.2 explains the rationale for approaching the investigation in a certain way (i.e. section 3.2 explicates a viable methodological means by which reliable knowledge regarding a market strategy for increasing public value is planned, structured, and executed to comply with the criteria of the demands of The Philosophy of Science and The Philosophy of Economics. Section 3.3 explains a theoretical and methodological framework for determining how to transform fundamental concepts into general conceptual categories for an integrative marketing theory.

\subsection{Developing an Integrative Marketing Theory}

"Theory is a structure of general statements that explains some phenomena and permits predictions about them". Theory development involves determining a process by which a phenomenon will be analyzed in order to better understand and explain the general aspects of the phenomenon. However, a theory that is to be applied by the marketing profession involves developing "Systematic structures that explain, predict, and assist in understanding" how to create relationships/market exchanges that are beneficial and satisfying for those involved in a transaction network. [71, 72] Wroe Alderson proposed that theory development begins with explaining the primary conceptual categorizations of marketing in terms that can be applied to the practice of and research regarding marketing. Alderson also stressed that the formal categorizations must be inclusive of conceptualizations of social action, integrated systems, organizational behavior, and social-economic performance. Shelby Hunt - noted for sustaining the interest in marketing theory - asserts that theory development requires establishing systematically categorized statements that explain the law-like generalities of a phenomenon in terms that are applicable to performance or can be tested by research. This article claims that developing a theory for how marketing strategies increase the value outcomes for stakeholders requires synthesizing the conceptualizations of the market, exchange, and valuation in such a way that they establish an axiomatic system that reflects fundamental postulates from which an integrative marketing theory can be derived. [76, 77].

Increasingly marketing specialists acknowledge the need for developing an integrative marketing theory. An integrative model can be defined as a strategy for conjoining the conceptual foundations of marketing, the new relational conceptualizations of marketing (i.e. the notion that the marketplace is an integrated network of interactions facilitated by telecommunications and information communication technology), with the marketing mix and the four P's). [78-83] However developing an integrative framework for marketing is complicated by the need to clarify the connection between the market, exchange, relational networks of resource integration, and value creation. The primary purpose of this article is to explore the prospect that there are, inherent in the literature on valuation, key principles and concepts that can be developed into an integrative framework in that they are consistent with the foundational principles and indicative of the new dominant logic in marketing.

On the basis of the foundational conceptualizations put forth by Aristotle and reasserted by Alderson an integrative strategy for increasing satisfactory and beneficial outcomes for stakeholders is grounded on three general categorizations that can be deduced from the literature: the relational and integrative systems model of market activity, the market as a public value-creation network, and the market as a structure where interactions result in integrating the resources of the system to increase the benefits for its stakeholders. [84-88] Verifying that the foundational conceptualizations apply to contemporary marketing strategies requires analyzing the current literature to determine how the foundational categorizations compare with contemporary conceptualizations of marketing exchange and valuation. 


\subsection{The Methodology for Developing an Integrative Marketing Theory}

The methodology for this article is an explanation of the rationale for taking a particular approach to developing an integrative marketing theory. This article undertakes an exploratory study of the literature as the means for determining how conceptualizations of marketing put forth in the literature can be articulated as the fundamental concepts of marketing science thus how conceptualizations contribute to the need to explain the relationship between marketing and stakeholders in terms that contribute to an integrated marketing theory.

Contemporary exponents of marketing's fundamental concepts point out that there is a shift toward an integrative approach to practicing marketing. In this sense an integrative approach to marketing is thought of as increasing beneficial relationships between stakeholders by means of establishing integrated processes and networks. However, although there is a shift — brought about by the decline of production dominant logic and the assurgency of both service dominant logic and value creation - some aspects of the established conceptualizations of marketing are still emphasized by prominent scholars as the core concepts of marketing. In this respect the marketing mix, exchange and transactions, and products and services (offering) must be included along with relationships, networks, and value (i.e. satisfying needs, wants, and demands with quality) to make-up the primary conceptualizations of marketing. Thus, establishing an integrative marketing theory involves re-conceptualizing the "fundamental explanada" of marketing in order to establish a general theory that encompasses the categorizations emphasizing particular aspects of the practice of marketing. Above all although a generalized marketing theory embraces transaction and exchange it also emphasizes that "Exchanges depend on customer value therefore customer value is the fundamental basis of all marketing activity".

It must also be kept in mind that an integrative model for the practice of marketing must conjoin three sets of fundamental conceptualizations: those that held from the foundational conceptualizations of the market, exchange, and valuation until the industrial era; those introduced during the mass production and consumption era; and recent contemporary conceptualizations of the practice of marketing. Plus, in keeping with The Philosophy of Science criteria for "Increasing scientific understanding through a systematized structure capable of both explaining and predicting phenomena" this article simplifies the systematically categorized statements in such a way that gives them a wider or more general explanatory power \& In its simplest form the fundamental concepts of marketing are the market, market segmentation, and marketing itself. However, explanatory power is also increased by elaborating on each of the three. For example, the market - a structure or system of interactions that integrate the resources of a system to increase the benefits for its stakeholders; market segmentation - the particular marketing segments for which value propositions are made, in the form of products and services, in the endeavor to meet the needs, wants, and demands of the consumers of such subsets; and marketing the practice of establishing integrated value-creating processes and networks. This simplified explanation indicates that the essential elements of the foundational approach are complementary with contemporary marketing strategies (i.e. the marketing mix and relational marketing) thus has a distinct strength which satisfies the need to indicate how contemporary conceptualizations can be explained in terms of factors that enhance practice.

\subsection{Methodological Means for Developing an Integrative Market Theory}

This section of explains how marketing conceptualizations can be used to develop a general theory of marketing? The historical and contemporary literature express conceptualizations that are complementary with the marketing mix and the four P's. Marketing initially focused on the exchange of products and services between the company and the consumer which placed the emphasis on value extraction. The new definition of marketing proposes that all points of interaction between the company and the consumer are opportunities for value creation and extraction thus the market becomes a system of interactional networks. $[96,97]$ Contemporary conceptualizations expands the notion of exchange from what takes place solely between a business and its customers to a social economic system within which exchange activity is embedded. The integrative practice of marketing is based on the conviction that "Societal needs, not just conventional economic needs, define markets". In this sense "A simple article of merchandise and the artistic condition (of economics, politics, law, art, etc.) reproduce the social structures in which they are constituted. Their specifically cultural value and their commercial value [are] reinforced [by] the economic sanction of their cultural consecration".

The expanded theoretical scope for a marketing theory reflects the scholarly urge to better understand the managerial consequences of transformations taking place and to identify factors that generate superior firm performance in constantly evolving competitive environments. Theory development provides this better understanding by describing the general categories that apply to marketing as the means for developing an integrative theory that can applied and tested by future researchers. Devising such a framework provides future researchers with an effective theoretical tool for analyzing, understanding, explaining, and making predictions about the contemporary practice of marketing. In this respect the theoretical framework for an integrative marketing theory would be:

The market is a structure, system, or network of interactions that integrate the resources of the system to increase the benefits for its stakeholders. Marketing is the practice of making value propositions to particular segments 
of the market, in the form of products and services, in the endeavor to meet the needs, wants, and demands of the consumers of such subsets. The market operates most effectively and the practice of marketing is most effective when they both operate to establish integrated value-creating processes and networks.
Thus, the current resurgence of the notion of the market as a public value creation sphere prompts three research questions regarding the prospect of an integrative marketing theory that are addressed in this article:

Is there inherent in the literature on valuation key principles and concepts that can be.

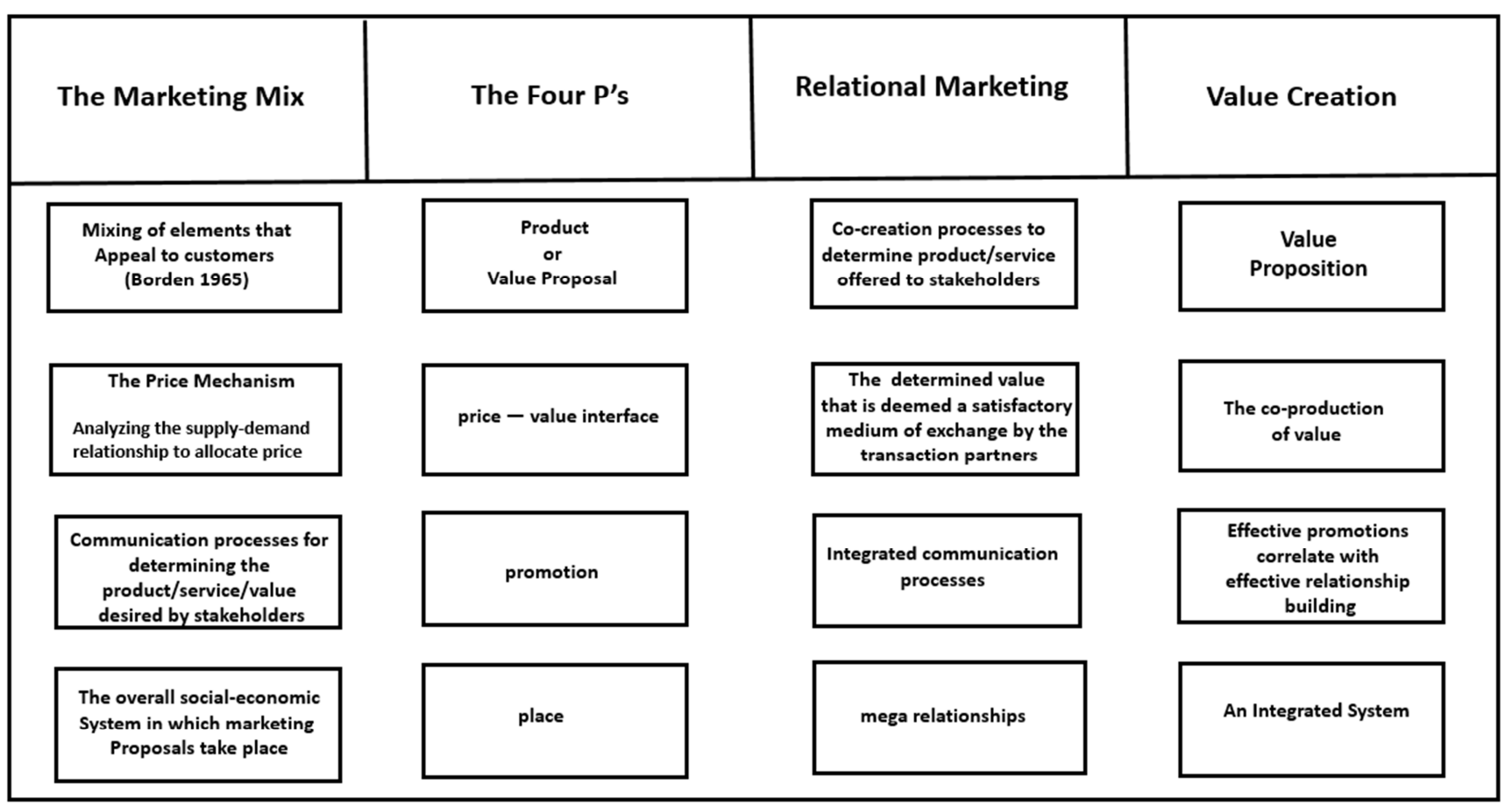

Figure 1. Parallel Comparison of The Marketing Mix, The Four P's and Relational Marketing/The Value Creation Concept.

Can an integrative marketing theory contribute to resolving the long-standing dichotomy between the value in exchange and value in use perspectives on economic value theory and, by doing so, contribute to a general theory of marketing?

Conceptualizations of market exchange, valuation, and social economic performance indicate the possibility of a complementary connection between the firm-centric endeavor to increase profit (i.e. competitive advantage) and the endeavor to increase customer or stakeholder satisfaction. Thus, the integrative concept contributes to developing a marketing theory that resolves the discrepancy between the value in exchange and value in use economic value theories.

What are the implications of applying the principles and concepts related to a marketing perspective on valuation and exchange toward developing a theoretical framework for cocreating stakeholder satisfaction (i.e. creating a strategy for the market operating as a public sphere where agents employ Structuration-type processes to co-create benefits for stakeholders)?

The exploratory study of the literature reveals that there is a congruence between strategies for integrating the interests of organizations (i.e. structures) and those of its clients/stakeholders (i.e. agents)). In other words, the integrative framework proves to be effective as a networking strategy because it concurs with the integrative systems theory approach for enhancing social-economic performance. Both the value creation concept and the integrative systems approach to improving performance emphasize that organizations are embedded within the overall social system and all aspects of the system can be structured to create interactive networks that integrate all social resources for the benefit of other segments of the system.

\section{Conclusion}

Alderson pioneered the place of theory in marketing by proposing the need for an inclusive approach to the development of marketing theory and for broadening the framework for marketing practice, study, and research. Alderson's call for theoretical inclusiveness seems equally valid today as there, is once again, a need for "Formulating the conceptual foundations and marketing methodologies that expand the scope of the marketing management theory to include the impact of information and communication technologies as major actors of the $21^{\text {st }}$ century marketing". That is to say that although the marketing mix paradigm continues to offer positive benefits to marketing thought, research, and practice there are now "New approaches [that] have been emerging in marketing research" that, as well, contribute to the theory and practice of marketing.

The new developments coincide with marketing specialists 
acknowledging that their professional activity is not limited to profit seeking but inclusive of enriching the entire society - based on the conviction that "The roots of marketing theory are in the cultural context of society". Thus, a new definition of marketing was approved in 2013 stating that "Marketing is the activity, set of institutions, and processes for creating, communicating, delivering, and exchanging offerings that have value for customers, clients, partners, and society at large". The change prompted a resurgence of discussions about the relevancy of a meta marketing theory that would encompass the full nature and scope of the marketing profession. [107, 108] The re-evaluation of the foundational principles of market transactions reveals that it contains the conceptual framework for an integrative model for marketing. Thus, the new movement toward an inclusive marketing framework is actually a reinstatement of the foundational relational and integrative model which is a means for increasing both social and economic value. [109112].

Increasingly specialists today are convinced that the inclusive/integrative marketing theory contributes to improving organizational and economic performance in ways that create better value outcomes for stakeholders. [113, 114, 83] That is to say that experts are increasingly convinced that the integrative marketing theory proves to be a progressive model for social-economic planning because it is a model for conjoining constructivist processes for social-formation with contemporary marketing strategies for co-creating stakeholder satisfaction. $[116,117]$ It is in this respect that the integrative marketing theory democratizes value creation (e.g. by proposing a participatory inclusive model for cocreating progressive and sustainable social-economic development). The increase in public value is generated by a network of stakeholders engaged in collaborative interactions which comes about as a result of three processes: "Social validation, social information, and social inspiration".

Thus, this article contributes to the literature proclaiming the need for marketing theory development as well as the literature asserting that marketing could benefit from a meta theory. It does so by drawing from the foundational principles to develop a theory of marketing that reconciles the dichotomy between social value theory and economic value theory. The article explains that the integrative marketing theory enhances social economic performance by "Constructing value through co-creation processes where both parties shape the value creation process". Specialists acknowledge that the integrative marketing strategy for performance improvement creates value for individual stakeholders and, as well, contributes to creating value beneficial for the overall society. However, the article also provides significant insight for practitioners and future researchers by explaining factors that play a role in making the integrative marketing theory an effective social network strategy for improving organizational performance and social-economic performance.

\section{References}

[1] Mick, David. \& Oswald, Laura. (2006) The semiotic paradigm on meaning in the marketplace. (Belk, Russell. Edit.). Handbook of Qualitative Research Methods in Marketing. Cheltenham, UK: Edward Elgar Publishing Limited, 31-43.

[2] Kotler, Philip. \& Zaltman, Gerald. (1971) Social Marketing: an approach to planned social change. Journal of Marketing. Volume 35, 5.

[3] Martin, Diane. \& Schouten, John. (2014) Sustainable Marketing through the Natural Step. Humanistic Marketing. (Varey, Richard. \& Pirson, Michael. Edits.). Hampshire, UK: Palgrave MacMillan, 231-243.

[4] Prahalad, C. \& Ramaswamy, Venkat. (2004) Co-creation Experiences: The Next Practice in Value Creation. Journal of Interactive Marketing. Volume 18, Number 3, 10-11.

[5] Vargo, Stephen. \& Lusch, Robert. (2004) Evolving to a New Dominant Logic for Marketing. Journal of Marketing. Volume 68, Issue 1, 1-17.

[6] Porter, Michael \& Kramer, Mark (2011) Creating shared value. Harvard Business Review.

[7] Miller, Leon. (2015a) A Marketing Strategy for Democratizing Value Creation. Research Journal of Economics, Business and ICT. Volume 10, Issue 1, 17-24.

[8] Parsuraman, A. (1982) Is a 'Scientist' versus 'Technologist' Research Orientation Conducive to Marketing Theory Development? Marketing Theory: Philosophy of Science Perspectives.1982 Proceedings of American Marketing Association (Bush, R. \& Hunt, S. Edits.). Chicago, IL: American Marketing Association, 78-79.

[9] Vargo, Stephen. Lusch, Robert. \& Akaka, Melissa. (2010) Advancing Service Science with Service-Dominant Logic: Clarifications and Conceptual Development. Handbook of Service Science. (Maglio, Paul. Kieliszewski, Cheryl. \& Spohrer, James. Edits.). New York: Springer Publishing, 140.

[10] Boulding, Kenneth. (1956) General Systems Theory: The Skeleton of Science. Management Science. Volume 2, Issue 3, 197-208.

[11] Boulding, Kenneth. (1966) The Economics of Knowledge and the Knowledge of Economics. The American Economic Review. Volume 56, Number 1/2, 1-13.

[12] [12.]Giddens, Anthony. (1984) The Constitution of Society: Outline of the Theory of Structuration. Oxford, UK: Polity Press, 24-25.

[13] Tanev, Stoyan. Knudsen, Mette. \& Gerstlberger Wolfgang. (2013) Value Co-creation as Part of an Integrative Vision of Innovation Management. Value Co-Creation: Best of TIM Review. (Tanev, Stoyan. \& Seppä, Marko. Edits.). Ottawa, Canada: Talent First Network.

[14] Johnson, Mark. Christensen, Clayton. \& Kagermann, Henning. (2008) Reinventing Your Business Model. Harvard Business Review. Issue 86, Number 12, 50-59.

[15] Drucker, Peter. (1994) The Theory of the Business. Harvard Business Review. Volume 72, Number 5, 95-104. 
[16] Miller, Leon. (2015a) A Marketing Strategy for Democratizing Value Creation. Research Journal of Economics, Business and ICT. Volume 10, Issue 1, 17-24.

[17] Lamb, Charles. Hair, Jr., Joseph. \& McDaniel, Carl. (2009) Essentials of Marketing. Mason, Ohio: South-Western Cengage Learning, 4.

[18] Kotler, Philip. Armstrong, Gary, Wong, Veronica. \& Saunders, John. (2008) Principles of Marketing. Essex, England: Pearson Education Limited.

[19] Searing, Elizabeth. \& Searing, Donald. (2016) A Basic Primer: People to Know. Practicing Professional Ethics in Economics and Public Policy. Dordrecht, The Netherlands: Springer Publishing.

[20] Vargo, Stephen. \& Lusch, Robert. (2004) Evolving to a New Dominant Logic for Marketing. Journal of Marketing. Volume 68 , Issue 1, 1-17.

[21] Ng, Irene. \& Smith, Laura. (2012) An Integrative Framework of Value. Toward a Better Understanding of the Role of Value in Markets and Marketing. Bingley, UK: Emerald Group Publishing Limited, 208-244.

[22] Aristotle. (2004) Nicomachean Ethics. (Crisp, Roger. Trans. Edit.). Cambridge, UK: Cambridge University Press.

[23] Weber, Max. (1964) The Theory Of Social And Economic Organization. New York: The Free Press.

[24] Parsons, Talcott. (1949) The Structure of Social Action. Glencoe, Illinois: The Free Press.

[25] Schmoller, Gustav. (1894) The Idea of Justice in Political Economy. Annals of the American Academic of Political and Social Science. Volume 4, 1-41.

[26] Schumpeter, J. (1936) The theory of economic development. Cambridge, MA: Harvard University Press, 3.

[27] Pawar, Badrinarayan. (2009) Theory Building for Hypothesis Specification in Organizational Studies. New Delhi: Response Books, 1-4.

[28] Pawar, Badrinarayan. (2009) Theory Building for Hypothesis Specification in Organizational Studies. New Delhi: Response Books, 10-11.

[29] Aristotle. (2004) Nicomachean Ethics. (Crisp, Roger. Trans. Edit.). Cambridge, UK: Cambridge University Press, 89-92.

[30] Flyvbjerg Bent. (2001) Making Social Science Matter: Why Social Inquiry Fails and How it Can Succeed Again. Cambridge, UK: Cambridge University Press, 130.

[31] Aristotle. (2004) Nicomachean Ethics. (Crisp, Roger. Trans. Edit.). Cambridge, UK: Cambridge University Press, 89-92.

[32] Aristotle (1959) Politics. (Rackham, H. Trans.) London: William Heinemann LTD, 9 \& 37-49.

[33] Vargo, Stephen. Maglio, Paul. \& Akaka, Melissa. (2008) On Value and Value Co-creation: A Service Systems and Service Logic Perspective. European Management Journal. Volume 26, Issue 3, 145-52.

[34] Aristotle. (2004) Nicomachean Ethics. (Crisp, Roger. Trans. Edit.). Cambridge, UK: Cambridge University Press, 106-124.

[35] [35.]Rossides, Daniel. (1998) Social Theory: Its Origins,
History, and Contemporary Relevance. Dix Hills, New York: General Hall, Inc, 22-30.

[36] Aristotle. (2002) DeAnima, (Hamlyn, D. W. Trans.). Oxford, Clarendon Press, 24.

[37] Nussbaum, Martha. (1978) Aristotle's De Motu Animalium. Princeton, New Jersey: Princeton University Press, 337.

[38] [38.] Aristotle. (2004) Nicomachean Ethics. (Crisp, Roger. Trans. Edit.). Cambridge, UK: Cambridge University Press, $36-48$.

[39] Lessem, Ronnie. \& Schieffer, Alexander. (2010) Integral Research and Innovation:Transforming Enterprise and Society. Surry, England: Gower Publishing Limited, 300.

[40] Aristotle. (2004) Nicomachean Ethics. (Crisp, Roger. Trans. Edit.). Cambridge, UK: Cambridge University Press, 106-124.

[41] Scollon, Ron. (2001) Mediated Discourse: The Nexus of Practice. London: Routledge, 163.

[42] Aristotle. (1984) The Complete Works of Aristotle. (Barnes, Jonathan. Edit.). Princeton, New Jersey: Princeton University Press, 184 \& 193-199.

[43] Bertalanffy, Ludwig Von. (1972) The History and Status of General Systems Theory. The Academy of Management Journal. Volume 15, Number 4, 407-426.

[44] Aristotle. (2004) Nicomachean Ethics. (Crisp, Roger. Trans. Edit.). Cambridge, UK: Cambridge University Press, 105-106.

[45] Aristotle. (1984) The Complete Works of Aristotle. (Barnes, Jonathan. Edit.). Princeton, New Jersey: Princeton University Press, 331-334.

[46] Miller, Leon. (2015b) A Methodological and Theoretical Framework for Social Economic Value Theory. International Journal of Social Economics. Volume 44 Issue 2, 169-180.

[47] Vargo, Stephen. \& Lusch, Robert. (2004) Evolving to a New Dominant Logic for Marketing. Journal of Marketing. Volume 68,6 .

[48] Vargo, Stephen. \& Morgan, Fred. (2005) Services in Society and Academic Thought: A Historical Analysis. Journal of Macromarketing. Volume 25, Number 1, 42-53.

[49] Smith, A. (2007). An Inquiry into the Nature and Causes of The Wealth of Nations. Hampshire, UK: Harriman House Ltd, 6-8.

[50] Miller, Leon. (2015a) A Marketing Strategy for Democratizing Value Creation. Research Journal of Economics, Business and ICT. Volume 10, Issue 1, 19.

[51] Stringham, Shand. (2012) Strategic Leadership and Strategic Management: Leading and Managing Change. Bloomington, Indiana: Universe, Inc, 103-107.

[52] Isaacs, William. (1999) Dialogue: The Art Of Thinking Together. New York: Currency Books, 118.

[53] Kotler, Philip. \& Scheff, Joanne. (1977) Standing Room Only: Strategies for Marketing the Performing Arts. Boston, Massachusetts: Harvard Business School Press, 76.

[54] White, Percival. (1926). Introduction: Market analysis as a basis for advertising. Advertising: Its problems and methods (Cover John. Edit.). New York: D. Appleton, 1-15. 
[55] White, Percival. (1921) Market Analysis: Its Principles and Methods. New York: McGraw Hill, 3.

[56] Jones, Brian. (2010) Marketing Theory. (Baker, Michael. \& Saren, Michael. Edits.). London: Sage Publication, Ltd, 52.

[57] Alderson, Wroe. (2006) Introduction to Functionalism. A Twenty First Century Guide to Aldersonian Marketing Thought. (Wooliscroft, Ben. Tamilia, Robert. \& Shiparo, Stanley. Edits). Boston: Kluwer Academic Publishers, 143$144 \& 168-174$.

[58] Dixon, Donald. (1990) Marketing as Production: The Development of a Concept. Journal of the Academy of Marketing Science. Volume 18, Number 4, 337-343.

[59] Alderson, Wroe. (2006) Introduction to Functionalism. A Twenty First Century Guide to Aldersonian Marketing Thought. (Wooliscroft, Ben. Tamilia, Robert. \& Shiparo, Stanley. Edits). Boston: Kluwer Academic Publishers, 166.

[60] Slowinska, Maria. (2014) Art/Commerce: the convergence of art and marketing in contemporary culture. Bielefeld, Germany: Transcript-Verlag Publications, 128-134.

[61] Varey, Richard. \& Pirson, Michael. 2014 Closing Commentary: Towards Humanistic Marketing? Humanistic Marketing. Hampshire, UK: Palgrave Macmillan, 276.

[62] Delanty, Gerard. (2005) Social Science. New York: Open University Press, 28.

[63] Kotler, Philip. (2005) The Role Played by the Broadening of Marketing Movement in the History of Marketing Thought. Journal of Public Policy \& Marketing. Volume 24 (1), 114 116.

[64] Peter, Paul. \& Olson, Jerry. (1983) Is Science Marketing? Journal of Marketing. Volume 47, 111-145.

[65] Guillet de Monthoux, Pierre. \& Strati, Antonio. (2002) Modernity/art and Marketing/aesthetics - a Note on the Social Aesthetics of Georg Simmel. Consumption Markets \& Culture. Volume 5, Issue 1, 1-11.

[66] Simmel, Georg. (1971) Individuality and Social Forms. Chicago: University of Chicago Press, 43- 48.

[67] Giddens, Anthony. (1984) The Constitution of Society: Outline of the Theory of Structuration. Oxford, UK: Polity Press, 24-26.

[68] Hunt, Shelby. (2015) Marketing Theory: Foundations, Controversy, Strategy, and Resource- advantage Theory. Oxon, UK: Routledge, 175.

[69] Miller, Leon. (2016) A Theoretical Framework for Value Creation: A MultidimensionalStrategy/Model for Improving Social Economic Performance. Journal of Creating Value. 2(2) $1-11$.

[70] Risjord, Mark. (2014) Philosophy of Social Science. New York: Routledge Publishing, 38-40.

[71] Hunt, Shelby. (2011) On the intersection of marketing history and marketing theory. Marketing Theory 11(4) 483-489.

[72] Hunt, Shelby. (2015) Marketing Theory: Foundations, Controversy, Strategy, and Resource-advantage Theory. Oxon, UK: Routledge, 15-16.

[73] Alderson, Wroe. (2006) Introduction to Functionalism. A
Twenty First Century Guide to Aldersonian Marketing Thought. (Wooliscroft, Ben. Tamilia, Robert. \& Shiparo, Stanley. Edits). Boston: Kluwer Academic Publishers, 53.

[74] Alderson, Wroe. (2006) Introduction to Functionalism. A Twenty First Century Guide to Aldersonian Marketing Thought. (Wooliscroft, Ben. Tamilia, Robert. \& Shiparo, Stanley. Edits). Boston: Kluwer Academic Publishers, 53.

[75] Hunt, Shelby. (2015) Marketing Theory: Foundations, Controversy, Strategy, and Resource- advantage Theory. Oxon, UK: Routledge, 175.

[76] Popper, Karl. (2002) The Logic of Scientific Discovery. London: published by Routledge Classics, 50-54.

[77] Hempel, 2001) The Philosophy of Carl G. Hempel: Studies in Science, Explanation, and Rationality. (FETZER, JAMES). New York: Oxford University Press, 6.

[78] Morgan, Robert. \& Hunt, Shelby. (1994) The Commitment Trust-Theory of Relational Marketing. Journal of Marketing. Volume 58, 20-38.

[79] Hunt, Shelby. (2003) Controversy in Marketing Theory: For Reason, Realism, Truth, and Objectivity. Armonk, New York: M. E. Sharpe, 15-16.

[80] Hunt, Shelby. (2015) Marketing Theory: Foundations, Controversy, Strategy, and Resource-advantage Theory. Oxon, UK: Routledge, 77-79.

[81] Dholakia, Nikhilesh. Zwick, Detlev. \& Denegri-Knott, Janice. (2010) Technology, Consumers, and Marketing Theory. The SAGE Handbook of Marketing Theory. (Maclaran, Pauline. Saren, Michael. Stern, Barbara. Tadajewski, Mark. Edits.). London: Sage Publications, 494-506.

[82] Constantinides (2006) The Marketing Mix Revisited: Towards the 21st Century Marketing. Journal of Marketing Management. Volume 22, Issue 3-4, 407-438.

[83] Sheth, Jagdish. \& Sisodia, Rajendra. (2006) Does Marketing Need Reform: Fresh Perspectives on the Future. Oxon, UK: Routledge Publications, 3-4.

[84] Aristotle. (2004) Nicomachean Ethics. (Crisp, Roger. Trans. Edit.). Cambridge, UK: Cambridge University Press.

[85] Alderson, Wroe. (2006) Introduction to Functionalism. A Twenty First Century Guide to Aldersonian Marketing Thought. (Wooliscroft, Ben. Tamilia, Robert. \& Shiparo, Stanley. Edits). Boston: Kluwer Academic Publishers.

[86] Dixon, Donald. (1990) Marketing as Production: The Development of a Concept. Journal of the Academy of Marketing Science. Volume 18, Number 4, 337-343.

[87] Boulding, Kenneth. (1956) General Systems Theory: The Skeleton of Science. Management Science. Volume 2, Issue 3.

[88] Giddens, Anthony. (1984) The Constitution of Society: Outline of the Theory of Structuration. Oxford, UK: Polity Press.

[89] Grönroos, Christian. (2011) Value co-creation in service logic: A critical analysis. Marketing Theory. Volume 11, Issue 3, 279-301.

[90] Kotler, Philip. (2000) Marketing Management, Millennium Edition. Upper Saddle River, New Jersey: Prentice-Hall, Inc, 4-10. 
[91] Hunt, Shelby. (1983) General Theories and the Fundamental Explanda of Marketing. Journal of Marketing. 47, 9-17.

[92] Holbrook, Morris. (1994) The Nature of Customer Value: An Axiology of Services in the Consumption Experience. Service Quality: New Directions in Theory and Practice. (Rust, Roland. \& Oliver, Richard. Edits.). Thousand Oaks, California: Sage Publications, 22.

[93] Hunt, Shelby. (2002) Foundations of Marketing Theory: Toward a General Theory of Marketing. Armonk, New York: M. E. Sharpe Inc, 209-211.

[94] Hatfield, Gary. (2000) Philosophy of Science. Concise Routledge Encyclopedia of. Philosophy. London: Routledge, 804-808.

[95] Rossiter, John. (2001) What Is Marketing Knowledge? Stage I: forms of marketing knowledge. Marketing Theory. Volume 1, Number 1, 1 9-26.

[96] Prahalad, C. \& Ramaswamy, Venkat. (2004) Co-creation Experiences: The Next Practice in Value Creation. Journal of Interactive Marketing. Volume 18, Number 3, 10-11.

[97] Grönroos, Christian. (2011) Value co-creation in service logic: A critical analysis. Marketing Theory. Volume 11, Issue 3, 279-301.

[98] Porter, Michael \& Kramer, Mark (2011). Creating shared value. Harvard Business Review, 1-4.

[99] Bourdieu, Pierre. (1993) The Field of Cultural Production: Essays on Art and Literature. Cambridge, UK: Polity Press.

[100] Constantinides (2006) The Marketing Mix Revisited: Towards the 21st Century Marketing. Journal of Marketing Management. Volume 22, Issue 3-4, 407-438.

[101] Laamanen, Mikko. \& Skålén, Per. (2015) Collectiveconflictual value co-creation: A strategic action field approach. Marketing Theory. Volume 15, Issue 3, 381-400.

[102] Vargo, Steven. \& Lusch, Robert. (2011) Service-dominant logic: a necessary step. European Journal of Marketing. Vol. 45 No. $7 / 8,1298-13$

[103] Constantinides (2006) The Marketing Mix Revisited: Towards the 21st Century Marketing. Journal of Marketing Management. Volume 22, Issue 3-4, 407-438.

[104] Grönroos, Christian. (1994) From Marketing Mix to Relationship Marketing. Management Decision. Volume 32 Issue 2, 4-20.

[105] Bartels, Robert. (1970) Marketing Theory and Metatheory. Homewood, Illinois: Richard D. Irwin.
[106] American Marketing Association (2013) Definition of Marketing. American Marketing Association Press Announcement. Chicago, Illinois: AMA.

[107] Hunt, Shelby. (2015) Marketing Theory: Foundations, Controversy, Strategy, and Resource-advantage Theory. Oxon, UK: Routledge, 43.

[108] Zaltman, Gerald. Angelmar, Reinhard, \& Pinson, Christian (1971) Metatheory in Consumer. SV - Proceedings of the Second Annual Conference of the Association for Consumer Research. (Gardner, David. Edit.). College Park, Maryland: Association for Consumer Research, Pages, 476-498.

[109] Vargo, Stephen. \& Akaka, Melissa. (2012) Value Co-creation and Service Systems (Re) Formation: A Service Ecosystems View. Service Science. 4(3), 207-217.

[110] Giesler, Markus. (2003) Social Systems in Marketing. European Advances in Consumer Research Volume 6. (Turley, Darach. \& Brown, Stephen. Edits.). Provo, Utah: Association for Consumer Research. Pages: 249-256.

[111] Luhmann, Niklas. (2000) The Reality of the Mass Media. Cambridge, UK: Polity Press, 99.

[112] Miller, Leon. (2015a) A Marketing Strategy for Democratizing Value Creation. Research Journal of Economics, Business and ICT. Volume 10, Issue 1, 17-24.

[113] Kotler, Philip. \& Levy, Sidney. (1969) Broadening the Concept of Marketing. Journal of Marketing. Vol. 33, No. 1, $10-15$.

[114] Miller, Leon. (2015a) A Marketing Strategy for Democratizing Value Creation. Research Journal of Economics, Business and ICT. Volume 10, Issue 1, 17-24.

[115] Andreasen, Alan. (2002) Marketing Social Marketing in the Social Change Marketplace. Journal of Public Policy \& Marketing. Vol. 21, No. 1, 3-13.

[116] Macmillan, R. (2011) The Big Society and participation failure. People, Place \& Policy Online. Volume 5, Number 2, $107-14$.

[117] Jordan, Bill. (2010) Why the Third Way Failed: Economics, morality and the origins of the Big Society. Bristol, UK: The Policy Press, 1.

[118] Sinhav, Birud. (2011) Co-Creation of Value: Creating New Products through Social Media. International Journal of Management Research. Volume 2, Number 1, 6-15.

[119] Seligman, James. (2012) Customer Experience in Modern Marketing. Raleigh, North Carolina: Lulu.com 